\title{
ZAJIŠŤTOVÁNÍ ZÁKLADNÍHO ŠKOLSTVÍ OBCEMI A MĚSTY: VYBRANÉ POSTŘEHY
}

\section{PROVISION OF PRIMARY EDUCATION BY MUNICIPALITIES AND TOWNS: SELECTED REFLECTIONS}

\section{JUDR. MAREK STARÝ, PH.D.}

\section{Ing. ZuZANA KHENDRICHE TRHLÍNOVÁ, PH.D.}

Katedra práva a veřejné správy $\mid$ Department of Law and Public Administration

Vysoká škola finanční a správní, o.p.s. $\mid$ University of Finance and Administration

$\triangle$ Estonská 500, 10100 Praha, Czech Republic

E-mail:starym@seznam.cz,trhlinova@email.cz

\begin{abstract}
Anotace
Př́spěvek se zaměřuje na predstaveni vybraných aktuálních reformnich tendencí a záměrù České republiky voblasti základního školstvi a predpokládaným dopadĩm těchto změn do možností a potenciálu obci a měst podporovat rozvoj základniho školstvi na svém územi. Specifická pozornost je věnována současným legislativním krokủm v oblasti základního školství, zejména školskému zákonu a reformě financováni regionálniho školství. Představeny jsou i vybrané otázky změn rozpočtového určeni dani v souvislosti s financováním výdajů spojených se zabezpečováním základního školství. Závěry prezentované v textu jsou výsledkem analýzy stávajicich koncepčnich dokumentů a právnich předpisů i terénnich empirických poznatkì. Navrhované i realizované reformni kroky voblasti školského zákona i financováni základního školství jsou relevantni ve vztahu k současným potřebám veřejného sektoru $i$ vzdělávaci politiky, r̆ada specifických otázek však neni dostatečně ve stávajicich $i$ navrhovaných zménách reflektována, např. role krajü, financování nepedagogických pracovníků a školských služeb, finančni dopady vybraných úprav do rozpočtu obcí apod.
\end{abstract}

\section{Klíčová slova}

obce, základni školy, obecni rozpočet, školský zákon

\section{Annotation}

Contribution is orientated to the introduction of selected actual reform tendencies and objectives of Czech Republic in the domain of elementary schools. Contribution presents also supposed impacts of these changes to the possibilities and potential of local governments to promote the basic education on their territory. Specific attention is paid to the actual legislative changes in the domain of basic schools, mainly to the Education Acts and to the reform of regional education funding. Basic issues of the tax redistribution changes and their impacts to the local budget capacity to promote education are also mentioned in the text. Text is based on the analysis of actual legal acts and conceptions as well as empirical experiences. Proposed and actually realised reform tendencies in the education domain are relevant to the actual public sector needs and possibilities, especially in the education domain. Some specific issues and impacts of reform steps are not enough discussed in these days, e.g. the role of the regions in funding of some educational needs, funding of non-pedagogic staff in the elementary schools, financial impacts of supposed changes etc.

\section{Key words}

municipalities, Elementary schools, Municipal budget, The Education Act

JEL classification: 128 


\section{Úvod}

Lidské zdroje jsou v současné době chápány jako jeden z významných faktorů místního a regionálního rozvoje i zvyšování konkurenceschopnosti území. V kontextu procesů decentralizace a uplatňování principů subsidiarity se územní samosprávy stávají, vedle ústředních a nadnárodních institucí, významnými aktéry $\mathrm{v}$ definování cílů a koncepcí vzdělávací politiky, zejména $\mathrm{v}$ oblasti regionálního školství. Obce a města mohou sehrávat z hlediska zvyšování kvality lidských zdrojů významné funkce jak v oblasti předškolního a základního školního vzdělávání, tak i v oblasti dalšího vzdělávání a vzdělávání specifických sociálních skupin prostřednictvím podpory různých typů vzdělávacích projektů a programů.

Posilování role obcí a měst v oblasti vzdělávání je diskutováno i na mezinárodní úrovni v souvislosti s praktickou aplikací paradigmatu veřejného vládnutí. Obce a města mají v porovnání s dalšími institucemi vyšší možnosti vytvářet tzv. „lokální nebo regionální komunitní vzdělávací systémy“ (resp. centra), které jsou založené na vytváření a rozšiřování vzájemných vztahů a vazeb mezi všemi dotčenými aktéry (zaměstnanci a ředitelé škol, rodiče, kraje a ministerstva, neziskové organizace, místní asociace, zástupci podnikatelů a další). (Kilpatrick 2003, 3) Obce a města mají rovněž vyšší možnosti vstupovat do vzájemných konfliktů mezi individuálními zájmy a vzdělávacími potřebami různých sociálních skupin a zájmy dané společnosti a zprostředkovávat rovnováhu prostřednictvím sdílení odpovědnosti, posilováním dlouhodobé systematické komunikace, participace a spolupráce. (Kilpatrick 2003, 7) Obce a města mohou prostřednictvím vytváření a koordinace strategických partnerství sehrávat velice pozitivní role v inkluzivní vzdělávací politice s pozitivními dopady do sociální i ekonomické stabilizace regionu.

Potenciál obcí a měst podporovat zvyšování kvality lidských zdrojů v území a možnosti vytvářet a využívat nástroje zaměřené na vytváření stabilních vztahů mezi různými aktéry v oblasti vzdělávání jsou ovlivněny jak personální a finanční kapacitou jednotlivých lokálních vlád, tak i strategickými cíli a koncepcemi vyšších úrovní veřejné správy, zejména ústředních orgánů. Jedním z předpokladů úspěšné implementace vzdělávací politiky je harmonizace rolí jednotlivých úrovní vlády, centra, krajů a obcí. (Potůček 2005, 294) Významnou roli zde hraje přiznaná reálná autonomie místních samospráv v realizaci vzdělávací politiky i stabilita legislativního rámce, včetně možné flexibility školského systému.

V současné době probíhá, popř. je připravována a diskutována, řada dílčích legislativních změn, které mají dopad i na role a postavení obcí a měst v oblasti zabezpečování základního školství. Vedle zásahů do samotného školského jakožto primárního normativního fundamentu se jedná i o úpravu kritérií rozpočtového určení daní, různých typů dotací ve vztahu $\mathrm{k}$ zajištění a $\mathrm{k}$ podpoře vzdělávání a zejména o reformu financování regionálního školství ve vazbě na připravovanou optimalizaci škol. V př́spěvku jsou představeny některé dopady těchto reformních kroků do řízení a hospodaření obcí a měst.

\section{Cíle a metody}

Cílem příspěvku je představit vybrané současné právní a finanční otázky zabezpečování základního školství ze strany obcí a měst. Dílčím cílem př́íspěvku je naznačit konflikt mezi deklarovanou samosprávou obcí a měst a reálnou mírou závislosti obcí a měst na vnějším prostředí.

Závěry prezentované $\mathrm{v}$ textu jsou výsledkem analýzy stávajících koncepčních dokumentů a právních předpisů i terénních empirických poznatků.

\section{Obce, města a rozvoj vzdělávání: současné tendence a trendy}

Možnosti obcí a měst zajišt'ovat základní školství na svém území jsou ovlivněny do značné míry finančními zdroji, které mají k dispozici. Vedle vlastních zdrojů zde hraje významnou roli i vnějš́ 
pomoc krajů a státu ve formě přidělovaných prostředků a dotací na zajištění základního školství. V kontextu deklarovaných cílů zvyšování hospodárnosti a produktivity veřejného sektoru jsou v současné době diskutovány i otázky financování škol, kdy národní instituce usilují o zvyšování efektivity i regionální vzdělávací politiky prostřednictvím různých typů prooptimalizačních opatření. Zásadní vliv má pro obce z hlediska financování základního školství úprava rozpočtového určení daní a změny daňových sazeb a pravidel. Vedle rozpočtového určení daní je v současné době diskutován $\mathrm{i}$ návrh nového modelu financování regionálního školství, jehož cílem je ekonomické zefektivnění vzdělávacího systému na úrovni obcí, měst i krajů a zvýšení cílenosti finančních prostředků do oblasti vzdělávání. (Koncepční záměr reformy systému financování regionálního školství 2011:6)

Autonomie obcí a měst $\mathrm{v}$ oblasti zabezpečování základního školství je ovlivněna relativně malou mírou fiskální decentralizace. Obce (stejně tak jako kraje) nemají významnější možnosti ovlivňovat výši vlastních př́ijmů prostřednictvím daňové politiky a jsou do značné míry závislé na rozhodnutí státu o výši, resp. sazbě daní a o způsobech přerozdělování daňových výnosů do územních samospráv (tzv. sdílené daně tvoří vedle dotací významnou část prřijmů obcí a měst). Z hlediska zajištování základního školství mají významné dopady do finanční kapacity obcí a měst zejména úpravy daně z prŕijmů a DPH a změny kritérií rozpočtového určení daní.

Problematika stanovení pravidel a principů přerozdělování daňových výnosů prostřednictvím rozpočtového určení daní byla $\mathrm{v}$ minulosti často předmětem kritiky ze strany měst a obcí, zejména $\mathrm{v}$ souvislosti $\mathrm{s}$ absencí motivačních faktorů a s nespravedlivým nastavením kritérií přerozdělování daňových výnosů, které znevýhodňovaly zejména malé obce. Rozpočtové určení daní bylo $\mathrm{v}$ této souvislosti často měněno, poslední změny byly přijaty v průběhu roku 2012, s platností od 1.1. 2013. (Zákon o rozpočtových pravidlech). Př́nosem pro obce a města, zejména pro populačně menší obce, může být zahrnutí nového kritéria pro přerozdělování daní, jímž je počet dětí v mateřských a základních školách. Toto kritérium nahrazuje př́spěvek na školství (příspěvek na žáka), který byl dřive zahrnut do globální dotace, příspěvek na školství se nově stává součástí sdílených daní. Jeho váha je dána i dalšími kritérii (počet obyvatel, katastrální rozloha), předpokládá se však, že tato změna přispěje ke spravedlivějšímu rozdělování daní a posílení rozpočtů, především ve venkovských obcích a malých městech.

Změnou koeficientů a kritérií RUD rovněž končí povinnost úhrad příspěvků za žáky, kteří dojiždí do mateřských nebo základních škol do jiných měst, tato změna se promítne v rozpočtech obcí a měst diferencovaně, negativní dopad bude mít zejména ve větších městech s intenzivnější spádovostí škol. Konkrétní dopady této změny do rozpočtů obcí a měst nejsou zatím dostatečně známy, vedle samotné výše př́ijmů v rozpočtech je však nezbytné hodnotit i dopady této změny na vývoj funkčních vztahů v území, zejména mezi městy a jejich zázemím, resp. mezi spádovými centry a malými obcemi. V souvislosti s připravovanou komplexní reformou financování regionálního školství (viz níže v textu) se rovněž uvažuje o převedení finančního zabezpečení nákladů na zaměstnance škol do RUD, tyto návrhy jsou však v současnosti ze strany územních samospráv odmítány.

Finanční potenciál obcí a měst v oblasti zajištování základního školství je s účinností od prvního ledna letošního roku ovlivněn nejen změnami koeficientů a kritérií rozpočtového určení daní, ale také navýšením výše sazby daně z přidané hodnoty. Výnosy z daně z přidané hodnoty patří rovněž do kategorie sdílených daní, navýšení sazby DPH a předpokládané posílení státního rozpočtu tedy přinese i vyšší př́ijmy do rozpočtů obcí a měst. Dopady navýšení sazby daně z přidané hodnoty však mohou být ve výsledku i negativní zhlediska vývoje obecních rozpočtů. Posílení sazby daně z přidané hodnoty ovlivní nejen př́imovou, ale i výdajovou stránku obecních rozpočtů, zejména navýšením výdajů za energie a údržbu budov a zařízení mateřských a základních škol, které jsou majetkem obcí a měst. Výsledné dopady navýšení sazby DPH do rozpočtů obcí bude nezbytné detailněji analyzovat.

Významný dopad do financování a zabezpečování základního školství obcemi a městy bude mít rozsáhlá reforma financování regionálního školství, která by měla vstoupit v platnost od ledna 2014. Tato reforma, která byla schválena jako základní koncepční dokument ministerstvem školství, mládeže a tělovýchovy v roce 2011, je dlouhodobě předmětem diskusí mezi zástupci ministerstva a 
zástupci obcí a měst. (Koncepční záměr reformy systému financování regionálního školství 2011) Představitelé územních samospráv vnímají zejména negativně ekonomická kritéria vázána na počty žáků ve třídách (původní návrh počítal s 24 žáky na třídu a min 3 třídami v každém ročníku, v současnosti se hovoří o normě 17 žáků na třídu). Stanovení těchto kritérií může mít negativní dopady na možnosti zajištění základního školství v malých obcích. Zejména představitelé venkova se obávají rušení škol s negativními dopady do rozvoje území ve smyslu oslabení ekonomických i sociokulturních funkcí venkova, snížení pracovních příležitostí, dostupnosti základního vzdělávání, zvýšení nákladů rodin v souvislosti s nucenou dojižd'kou do škol i oslabení volnočasových aktivit vázaných na existenci škol.

Reforma financování regionálního školství je cílena nejen na ekonomickou optimalizaci škol, ale také na řešení některých dalších současných problémů financování regionálního školství, mezi něž patří zejména vysoké rozdíly v rozpočtech mezi srovnatelnými školami.

Kvalita vzdělávání na jednotlivých školách by měla být posílena o tzv. normativy rámcových vzdělávacích programů, které jsou závazným základem pro stanovení výše finančních prostředků přidělovaných do škol a jejichž zohlednění nebylo dosud plně ve financování reflektováno. Pozitivní př́nos do financování a přidělování prostř̌edků může přinést pevné stanovení oborových normativů na žáky ze strany ministerstva. Problém však zůstává, že tyto normativy budou pevně a pro všechny jednotně stanoveny jen pro pedagogické pracovníky, financování nepedagogických pracovníkủ budou moci i nadále měnit krajské úřrady, často bez transparentně stanovených pravidel a principů. Vzhledem $\mathrm{k}$ tomu, že výchova a vzdělávání tvoří jeden kompaktní celek, měla by být tato problematika i nadále diskutována a sjednocena.

V rozhodování o výsledném využití přidělených prostředků budou, podle návrhu na změnu financování regionálního školství, posíleny pravomoci ředitelů škol. (Koncepční záměr reformy systému financování regionálního školství 2011) Zde se otevírá prostor pro obce a města, jako zřizovatele mateřských a základních škol, pro stanovování jasných kritérií při výběru a jmenování ředitelů škol (k problematice jmenování a odvolávání ředitelů škol v souvislosti s novelou školského zákona se vracíme níže $\mathrm{v}$ textu). Posílené finanční pravomoci mohou ovlivnit i vliv ředitelů na celkovou kvalitu školy a její význam v dané lokalitě či širším spádovém území. Efektivní spolupráce mezi obcemi a školami a tlak na kvalitu rozhodování managementu škol tak bude moci přispět i k posilování významu a postavení škol z hlediska jejich vzdělávacích, finančních i identifikačních funkcí v daném území.

Současné návrhy na reformu financování regionálního školství jsou výsledkem široké diskuse mezi zástupci ministerstev, územních samospráv a dalších dotčených organizací a subjektů. Mezi jednotlivými partnery existuje shoda na významu a předpokládaných pozitivních dopadech navrhované reformy. Hodnocení dopadů zavedení reformy do rozvoje škol a obcí a měst je však obtížné, nebot' nejsou zatím jednoznačně stanovena kritéria pro financování škol. Problémem zůstává zejména absence způsobu výpočtu oborového normativu a nákladů na vzdělávací programy (oborový normativ bude definován diferencovaně ve vztahu ke stupni organizovanosti školy, resp. jejímu rozsahu zajišt'ování výuky na prvním a druhém stupni), včetně způsobů výpočtů tzv. doplňkové částky (stanovuje se dle typu škol). Dostatečně není řešena ani otázka financování tzv. svazkových škol, tedy škol zřizovaných dobrovolnými svazky obcí (školský zákon, 2004), resp. zavedení finančních motivačních nástrojů pro zabezpečení vzdělávání prostř̌ednictvím svazkových škol např. posílením doplňkové částky. Podpora těchto typů škol má jednoznačné pozitivní administrativní a ekonomické dopady z hlediska rozpočtů malých obcí a v kontextu deklarovaných optimalizačních cílů financování regionálního školství by měla být tato spolupráce mezi obcemi v oblasti zajišstování základního školství více podporována

Obecně lze konstatovat, že navrhovaný systém financování regionálního školství má potenciál přispět k vyšší míře hospodárnosti i $\mathrm{k}$ posílení finančních prostředků zejména pro menší obce a školy s nižšími počty žáků ve srovnání se současným stavem (zejména prostřednictvím doplňujících částek). Pro dlouhodobě udržitelné financování základních škol by však bylo vhodné stanovit střednědobé 
plány financování školství na národní i krajské úrovni i střednědobé výhledy souvisejících legislativních norem, metodických postupů i finančních vazeb.

Ačkoliv je otázka financování hlavním tématem současných debat, jistě nepředstavuje jediný rozměr reformy regionálního školství. Je například načase začít analyticky vyhodnocovat zkušenosti s novým nastavením vztahu mezi obcemi jako zřizovateli škol a řediteli škol jako osobami, zastávajícími dvojjedinou a do jisté míry dalo by se ř́ci př́mo schizofrenní úlohu. Na jedné straně jsou garanty vzdělávacího procesu, zajišt'ovaného jako výkon obslužné státní správy pod gescí MŠMT, na straně druhé pak vedoucími pracovníky obecních př́spěvkových organizací, jmenovaných starosty a s politickými orgány obce nutně kooperujících. K tomu přistupují ještě další role (Puškinová, 2013, s. $6)$.

Není asi nutné připomínat, že právě akcent na úlohu ředitele ve vzdělávacím procesu vedl $\mathrm{k}$ tomu, že v minulosti bylo odvolání ředitele zřizovatelem zhlediska právního velmi obtížné, $\mathrm{k}$ čemuž dlouhodobě prrispívala i soudní judikatura. Argumentováno bylo neodborností př́ípadných zásahů, které by mohly ohrozit kvalitu a kontinuitu výuky. Na druhou stranu bylo ale ze strany obcí dlouhodobě kritizováno, že samosprávná korporace jako zrrizovatel a poskytovatel zázemí i finančních prostředků nemá páku na to, aby se „zbavila“ ředitele, s jehož činností nebyla spokojena. Nevyhnutelně tak docházelo k četným pokusům o odvolání, které nenacházely $\mathrm{v}$ zákoně dostatečnou oporu a před soudem by jen stěží obstály (srovnej přehled, který sestavil Mikáč, 2011, s. 8). Ne všichni odvolaní ředitelé ale cestu soudního přezkumu nastoupili.

Kritika načrtnutého stavu našla svůj odraz v poslední zásadní novele školského zákona, provedené s účinností od 1. ledna 2012 zákonem č. 472/2011 Sb. (blíže Novela školského zákona, 2012). Šlo ovšem o krok vysloveně kompromisní - možnosti odvolání ředitele se zásadním způsobem nerozššririly, zřetelný posun ale znamená šestileté funkční období, které ředitelům odebírá „definitivu“ a perspektivně je nutí $\mathrm{k}$ vstřícnějšímu postoji $\mathrm{k}$ postojům představitelů samosprávy, jež je na chodu školy zainteresována nejen ekonomicky, ale rovněž z pohledu komunálního rozvoje.

Nepochybně by bylo př́nosné vyhodnotit proces výměny ředitelů, který na základních školách po nabytí účinnosti zmíněné novely nastal (byt' bylo vyhlášení konkurzů koncipováno fakultativně a řada obcí tak ponechala status quo). A to nejen kvantitativně, ale především z hlediska konkrétních zkušeností, které přinesla praxe. Právě ta totiž v celé jejich nahotě odkryla sporné momenty, které unikly pozornosti zákonodárce. Jen namátkou - pokud obec přistoupila ke změně na postu ředitele, musela řešit zařazení ředitele dosavadního. Logika věci by vedla k variantě, kdy po opuštění vedoucího místa obsazovaného jmenováním by měl pokračovat pracovněprávní vztah na pozici řadového pedagogického pracovníka. Pro toto řešení neexistovala ovšem patřičná opora $\mathrm{v}$ zákoně a postupovalo se podle analogických ustanovení zákoníku práce. Ta dávala bývalému řediteli možnost si vybrat, zda mu nabídnutý úvazek (byl-li mu ho nový ředitel vůbec s to nabídnout) vyhovuje. Pokud jej neakceptoval, řešila se tato skutečnost jako překážka v práci na straně zaměstnavatele. Vygeneroval se tak výpovědní důvod, s nímž nebyl spojen nárok na odstupné. Potud by bylo vše v pořádku. Podle převažujícího právního výkladu ale v případě překážky na straně zaměstnavatele není zaměstnanec povinen docházet na místo výkonu práce. Jinými slovy - ředitelé sice nedostali odstupné, v průběhu dvouměsíční výpovědní lhůty ale dostávali plný plat, aniž by do školy museli docházet. Pokud byli dostatečně akční, mohli v té době zároveň pobírat plat v novém zaměstnání. Netřeba snad podotýkat, že finanční náročnost tohoto řešení mohla být $\mathrm{v}$ malých vesnických školách $\mathrm{s}$ napnutým rozpočtem výrazným mementem nutícím $\mathrm{k}$ vážnému zamyšlení, zda výměnu stávajícího ředitele za třebas i kvalitnějšího kandidáta absolvovat.

Další dlouhodobě nedořešený problém představují také školské rady, povinně zřizované př̀i všech základních školách. Ohledně jejich fungování panují pochybnosti dlouhodobě (např. Husník Štefflová - Švancar, 2012, s. 13-16) a plasticky to vyniklo i při projednávání zmíněné novely školského zákona v Poslanecké sněmovně. Na jedné straně zaznívaly hlasy poukazující na formálnost mnoha školských rad a navrhující odsunutí tohoto orgánu do kategorie fakultativních (sněmovní tisk č. 340/2, bod 74), na druhé straně ale nakonec zvítězil právě opačný př́stup, vedoucí k posílení jejich 
kompetencí. Vedle dosavadního schvalování nejrůznějších dokumentů jim totiž novela nově přiznala právo navrhovat předčasné odvolání ředitele školy. Což je jediný nový důvod, pro který může dojít k ukončení jeho funkčního období i před uplynutím doby, na níž byl jmenován (Školský zákon, § 166 odst. 5 písm. b) a $§ 168$ odst. 1 písm. i)).

Z hlediska správní teorie je velmi pochybné, nakolik jsou školské rady skutečně specifickým projevem samosprávy, $\mathrm{k}$ níž jsou zpravidla řazeny (např. Horzinková - Novotný, 2010, s. 70). Samospráva je imanentně spojena s korporativní organizací společnosti, základní škola ale žádnou veřejnoprávní korporaci nepředstavuje a sama školská rada je místem, kde se mohou střetávat dílčí zájmy a postoje zaměstnanců, rodičủ a zástupců zřizovatele. Spíše než o self-government tu tedy jde o jakousi specifickou formu dozoru, čemuž odpovídají i samotné kompetence rady. Z hlediska praktického pak lze souhlasit $\mathrm{s}$ tím, že školská rada může být prostředkem k zapojení rodičů jako partnerů, přebírajících vyšší míru spoluzodpovědnosti za vzdělávání svých dětí, formálním prostředkem k realizaci této spoluzodpovědnosti. Zároveň tu je i prostor pro užší spolupráci obce jako zrrizovatele školy a pedagogických pracovníků jako primárních garantů vzdělávacího procesu. Zcela ale schází pozitivní motivační prvky, které by mohly občanskou společnost aktivizovat - samotné přiznání kompetencí, byt' rozšířených, tuto roli hrát nemůže. $Z$ tohoto pohledu lze predikovat, že i nadále bude úloha školských rad bytostně záviset na angažovanosti jejich členů a že př̀ mnoha školách bude jejich existence spíše jen nominální. Diskuse o možných cestách transformace školských rad (případně i o vhodnosti jejich povinného zřizování) se tak jeví jako velmi žádoucí, přičemž inspirace zahraničními vzory se tu hlasitě nabízí.

\section{Závěr}

Podpora vzdělávání má pro územní samosprávy zvláštní význam jak z hlediska zvyšování kvalifikace obyvatel, tak i z hlediska socializačních a integračních funkcí, výchovných funkcí i ochranných a kontrolních funkcí (sociální kontrola nezletilých a prevence kriminality), včetně podpory posilování lokální a regionální identity a sounáležitosti. Možnosti podpory vzdělávání na úrovni obcí a měst jsou ovlivněny mnoha faktory, kromě jiného i legislativním a finančním prostředím vyšších úrovní veřejné správy. V současnosti probíhá řada diskusí o reformě financování regionálního školství, jejichž výsledkem je jednak posílení kritérií v rámci rozpočtového určení daní a návrh systémové reformy financování regionálního školství.

V zásadě lze hodnotit výše uvedené změny kladně, nicméně stále chyb detailnější finanční analýzy reálných dopadů výše zmíněných změn do rozpočtů obcí a měst i konkretizace podmínek pro získávání některých finančních prostředků (např. podpora vzdělávání žáků se speciálními vzdělávacími potřebami, nejednoznačná kritéria pro rozhodování krajských úřadů o vzdělávání a nepedagogických pracovnících ve školách a školských zařízení zřizovaných obcemi, podpora svazkových obcí). V tomto smyslu může být spuštění reformy vzdělávání $\mathrm{k}$ lednu příštího roku považováno za nedostatečně koncepčně a realizačně připravené. Realizace reformy by měla být založena na postupných implementačních krocích, které umožní flexibilně řešit některé stávající nedořešené otázky a souvislosti a zároveň reagovat na dopady dalších souvisejících změn, které zajišt’ování základních škol ovlivňují (RUD, školský zákon apod.).

Vedle otázek ekonomických zůstává do budoucna prostor i pro další odbornou debatu o řadě dílčích problémů, např́klad pokud jde o vztah obce jako zrrizovatele školy a ředitele jako garanta vzdělávacího procesu a představitele státní správy sui generis. Stejně tak výzvou pro další diskuzi a rozšiřování prostoru pro participaci veřejnosti zůstávají i školské rady, jejichž kompetence byly sice zásadní novelou školského zákona $\mathrm{v}$ roce 2011 posíleny, ve skutečnosti ale hrají v mnoha př́ípadech jen velmi marginální a formální úlohu. Platformou k těmto diskuzím by se ovšem měla stát média ryze odborná a tomu by měla odpovídat i samotná podstata takových diskuzí. 


\section{Literatura}

[1] HORZINKOVÁ, E., NOVOTNÝ, V. Základy organizace veřejné správy. Plzeň: Aleš Čeněk, 2010. $233 \mathrm{~s}$.

[2] HUSNÍK, P., ŠTEFFLOVÁ, J., ŠVANCAR, R. Školská rada - vnucená př́ležitost. Učitelské noviny $8 / 2006$, s. 13-16

[3] KILPATRICK S. a kol. Defining learning communities. Discussion Paper D1/2003, CRLRA Discussion Paper. Launceston Tasmania: Centre for research and learning, 2003. 13 s.

[4] MIKÁČ, J. Př́ípady odvolání ředitelů škol a školských zařízení v letech 2010 a 2011 . Řizení školy 10/2011, s. 8

[5] MŠMT ČR. Koncepční záměr reformy systému financování regionálního školství. Praha: MŠMT ČR, 2011. $60 \mathrm{~s}$.

[6] Novela školského zákona 2012: praktické rady pro ředitele škol. Praha: Raabe, 2012. 98 s.

[7] POTŮČEK M a kol. Veřejná politika. Praha: Slon, 2005. $396 \mathrm{~s}$.

[8] PSP ČR. Sněmovni tisk č. 340/2. Usnesení výboru pro vědu, vzdělání, kulturu, mládež a tělovýchovu z 15. schůze ze dne 12. října 2011 k vládnímu návrhu zákona, kterým se mění zákon č. 561/2004 Sb., o předškolním, základním, středním, vyšším odborném a jiném vzdělávání (školský zákon), ve znění pozdějších předpisů (sněmovní tisk 340). [cit. 2013-04-30] Dostupné z $<$ http://www.psp.cz/sqw/text/tiskt.sqw?o=6\&ct=340\&ct1 $=2>$.

[9] PUŠKINOVÁ M. Ředitel veřejné školy - kolik „rolí hraje“ a za jakých podmínek? Řizení školy $4 / 2013$, s. 6

[10]Zákon č. 243/2000 Sb., o rozpočtovém určeni výnosů některých dani územním samosprávným celkuim a některým státním fondům (zákon o rozpočtovém určeni dani), ve znění pozdějších předpisů

[11]Zákon č. 561/2004 Sb., o předškolním, základním, středním, vyšším odborném a jiném vzdělávání (školský zákon)

Př́spěvek byl zpracován v rámci projektu interního grantu Vysoké školy finanční a správní, o.p.s. Praha „Nezávislost samosprávy v Čechách (?)“. 